EJP 21143

\title{
Short communication \\ WAY 120,491 activates ATP-sensitive potassium channels in rat tail artery
}

\author{
Philip B. Furspan \\ Departmen of Prysiology, Unicersity of Michigan. Ann Arbor, MI 48109, USA
}

Received 22 Juiy 1992. revised MS received 8 Septemler 1992. acepted 15 Septemher 1992

\begin{abstract}
WAY 120,491 lowers blood pressure in a number of animal models. Its mechanism of action appears to be the selective opening of $\mathrm{K}^{\prime}$ channels in vascular smooth muscle cells. The patch clamp technique was used to determine the specific $\mathrm{K}^{*}$ channel affected by WAY 120,491 in isolated tail artery cells of the rat. In the inside-out configuration. WAY 120,491 caused a dose dependent partial reversal of the ATP-induced inactivation of channel activity. Glyburide $(10 \mu \mathrm{M})$ almost completely inhibited the effect of WAY 120,491. WAY 120,491 had no effect on Ca-activated $\mathrm{K}^{+}$channels inactivated by the absence of $\mathrm{Ca}^{2}{ }^{2}$. In the whole cell configuration. $10 \mu \mathrm{M}$ WAY 120.491 increased outward $\mathrm{K}^{+}$current. 10 $\mu \mathrm{M}$ glyburide completely reversed the increase in current. WAY 120,491 appears to be a relatively specific activator of ATF-sensitive $\mathrm{K}^{+}$channels in vascular smooth muscic.
\end{abstract}

\section{$\mathrm{K}^{+}$channels; ATP; Smooth muscle (vascular); Patch clamp}

\section{Introduction}

During the past several years several chemically distinct compounds, e.g., pinacidil, diazoxide and cromakalim, have been shown to lower blood pressure by reducing peripheral resistance (Falotico et al., 1989). The main mechanism of action of these drugs appears to involve an increase in the efflux of $\mathrm{K}^{+}$ions from vascular smooth muscle cells and the resultant cell membrane hyperpolarization. Specifically, these compounds incscasc the open probability of ATP-sensitive $K$ channeis $\left(K_{\text {ATp }}\right)$ (Standen et al., 1989; Furspan and Webb, in press).

WAY 120,491 [(-)-(3S-trans)-2-[3,4-dihydro-3-hydroxy-2,2-dimethyl-6-(triflouromethoxy)-2H-i-benzopyran-4-yl]-2,3-dihyciro-1H-isoindol-1-one] is a novel benzopyran derivative that has been shown to lower blond pressure in a number of animal models (Oshiro and Colatsky, 1991). Pre-clinical data on this compound indicate that, as is the case for the drugs mentioned above, its mechanism of action is the selective opening of $\mathrm{K}^{+}$channels in vascular smooth muscle cells. WAY 120,491 increases the efflux of both ${ }^{\text {xi }} \mathrm{Rb}$

Correspondence to: P.B. Furspan, 7706 Medical Sciences H, Department of Physiology, University of Michigan, Ann Arbor. M! 4hlo!-

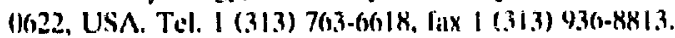

and ${ }^{42} \mathrm{~K}$ from rabbit aorta and rat portal vein (Edwards et al., 1990; Lodge et al., 1991). This effect could he blocked by glyburide, a specific antagonist of $K_{A T P}$. On the basis of this ability of glyburide to antagonize the relaxant effect of WAY 120,49 I in vitro, it has been postulated that this drug interacts with the ATP-sensitive $\mathrm{K}^{+}$chamnel.

In this study the patch clamp technique was to used to determine the specific $K$ channel affected by WAY 120,491 (supplied by Wyeth-Ayerst Research, Princeton, N.J.) in isolated tail artery cells of the rat.

\section{Materials and methods}

Adult male and female Wistar-Kyoto (WKY) rats (16-20) weeks old) were obtained from rat colonies maintained in the Department of Anatomy and Cell Biology, University of Michigan.

To isolate vascular smooth muscle cells, tail artery segments were incubated in tigestion medium $(\mathrm{mg} / \mathrm{ml})$ : collagenase (0.5), trypsin inhibitor (0.3), papain (0.4), dithiothreitol (0.3), bovine serum albumin (7.5); $\mathrm{pH} 7.4$ in physiological salt solution (PSS) [(mmol/1): $\mathrm{NaCl}$ 140; $\mathrm{KCl} 5.4 ; \mathrm{KH}_{2} \mathrm{PO}_{4} 0.44 ; \mathrm{NaH}_{2} \mathrm{PO}_{4} 0.42 ; \mathrm{NaHCO}_{3}$ 4.17; $\mathrm{CaCl}_{2}$ 0.5; HEPES 5 ; dextrose 5.55; $\mathrm{pH}$ adjusted to 7.4 with $1 \mathrm{~N} \mathrm{NaOH}$ ] for $90 \mathrm{~min}$ at $37^{\circ} \mathrm{C}$. Cells were then dispersed by trituration with fire-polished Pasteur pipettes of decreasing tip diameter. 
Single channd and whole cell $\mathrm{K}^{+}$currents were measured with standard patch clamp technique. A Dagan syolo Patch Clamp/Whole Call Clamp (Minneapolis. MN ('SA) was used to voltage clamp membrane in the whole cell and inside-out configurations. Single channel data were digitized using a modified digital audio processor (Sony PCM-701ES. Medical Systems Corp. Greenvale, NY USA) and recorded on videocassette tape for analysis. Whole cell data were stored on computer hard disk. Electrodes were prepared from borosilicate giass (Kimble R-6, Richland Glass, Richland. NJ USA).

The bath in the whole cell configuration and the pipette in the inside-out configuration contained (in $\mathrm{mM}$ ): $145 \mathrm{KCl}, 10 \mathrm{HEPES}$ ( $\mathrm{N}$-[2-hydroxyethyl]piperazine- $N$ '-\{2-ethanesulfonic acid]), 10 glucose and $\mathrm{KOH}$ to bring $\mathrm{pH}$ to 7.4. A $\mathrm{Ca}^{2}$-huffered solution was used as the transmembrane solution for both configurations. It contained (in mM): $11.3 \mathrm{KCl}, 2.02$ EGTA, 20.2 $K$, PIPES (piperazine- $N, N$ '-bis[2-ethanesulfonic acid); $\mathrm{pH}$ 7.0. For the whole cell experiments the pipette solution contained $1 \mathrm{mM}$ ATP. Sufficient $\mathrm{CaCl}_{2}$ was added to yield a calculated free $\mathrm{Ca}^{2+}$ concentration of I00 $\mathrm{nM}$ as described by Chang et al. (1988).

Computer analysis of single channol records was performed on a Gateway 2000 computer using
pCLAMP soltware (Axon Instruments) and auxiliary programs designed to read pCLAMP files. The auxiliary programs were used to calculate mean current from single channcl records (Richards et al., 1989).

Mean current was defined as the total charge carried through the channel(s) in the patch divided by the total time of the current record. Segments of data files containing digitized current records were identified which represented closed channel baseline. Mean current was then defined as the mean deviation from the defined baseline over the course of the record. Appropriate scaling factors were used to express the mean current in picoamperes (pA). This analysis can be applied to any patch in which a stable closed current baseline can be identified and therefore be used to analyze records containing more than one active channel and other current records for which an jucalized record cannot be easily constructed.

\section{Results}

\subsection{Inside-out configuration}

A 1 min baseline record was votained at $+20 \mathrm{mV}$ prior to adding to the bath in a cumulative fashion 1
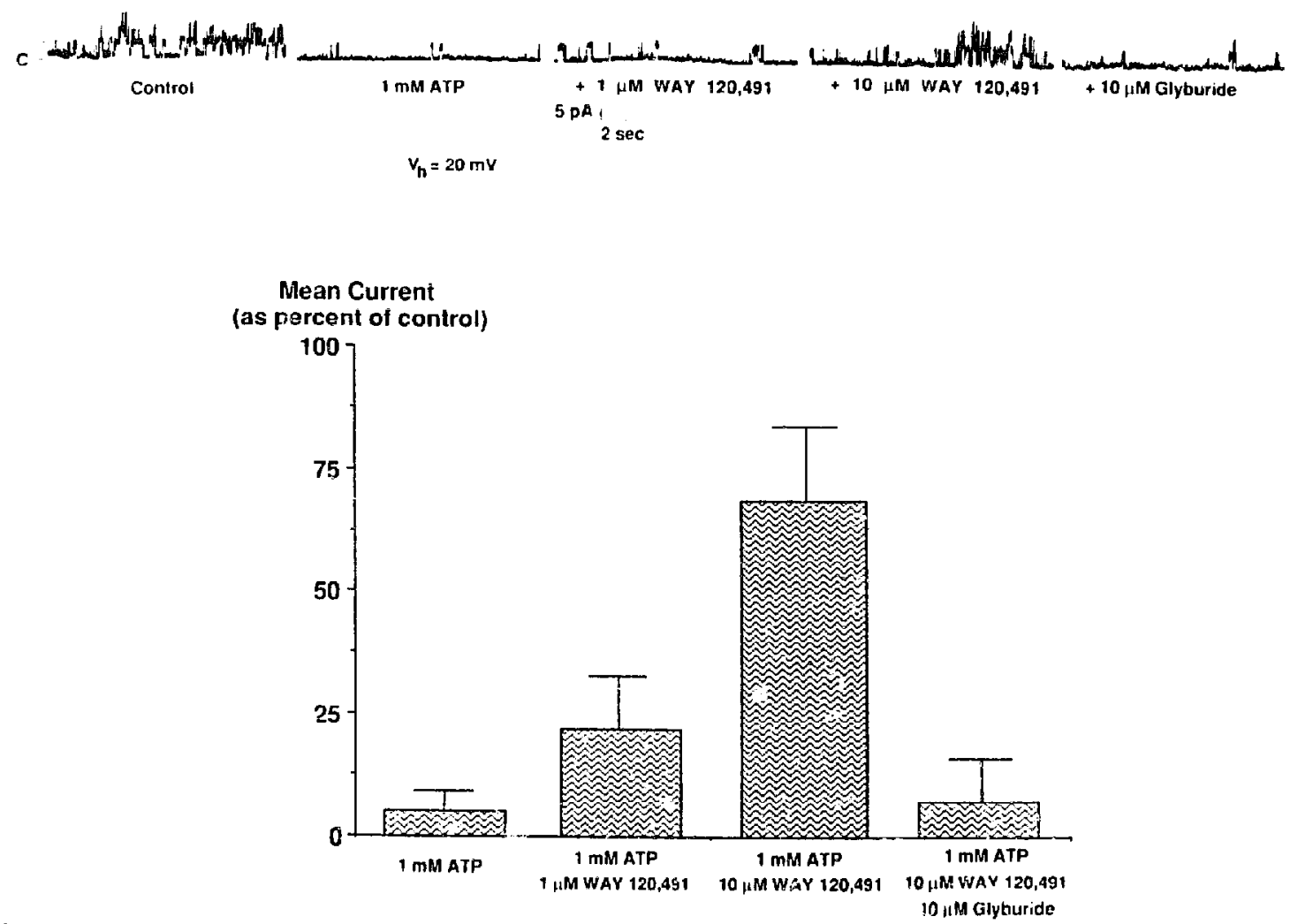

Fig. 1. Single channel currents of $K_{\text {ATP }}$ recorded from inside-out patches of rat lail ariery cell membranc. Top: rerresemative sracings of $K_{A T}$ under control conditiom (see text) and after the cumulative addition of $A T P$. WAY 120,49! and glyburide to ihe bath. Banttom: average response

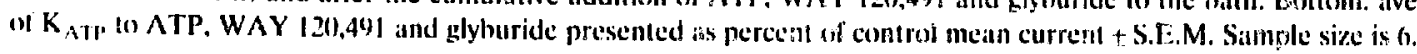




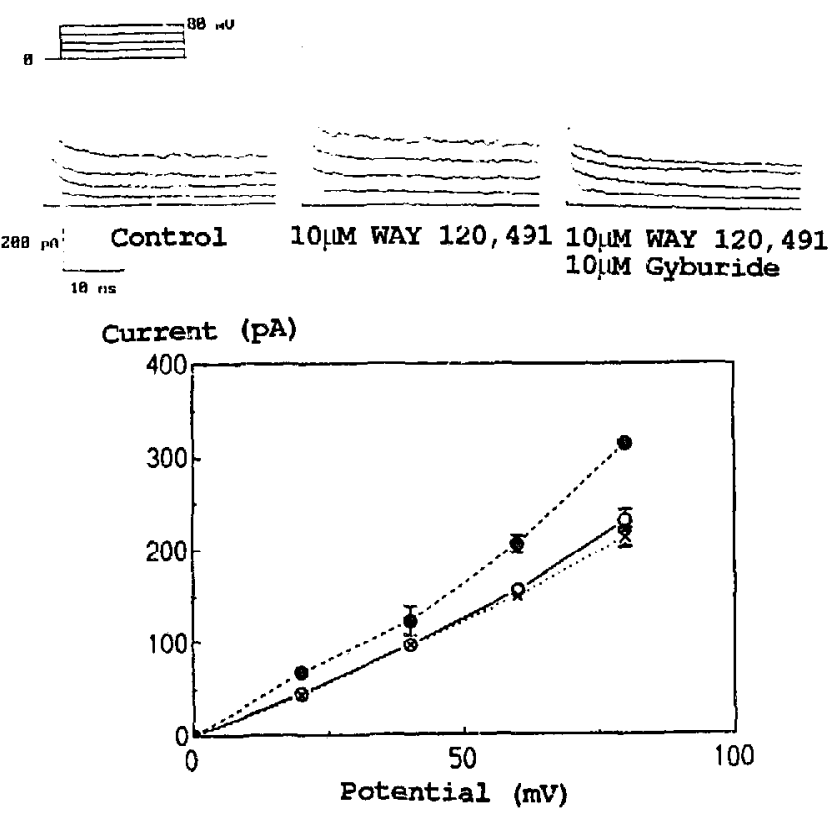

Fig. 2. Outward whole-cell $\mathrm{K}^{+}$current in rat tail artery cells. Top: representative iracings showing outward $\mathrm{K}^{+}$current in response to depolarizing command potentials from 0 to $80 \mathrm{mV}$ in $20 \mathrm{mV}$ increments under control conditions and in the presence of $10 \mu \mathrm{M}$ WAY 120.491 and glyburide. Bottom: mean current-voltage relationships of outward $\mathrm{K}^{+}$current ( $\mathrm{n}=5$ in each group) under control conditions (open circles) and in the presence of WAY 120,491 (filled circles) and glyburide $(x)$. Values are the means \pm S.E.M. $* P<0,05$, different from control.

niM ATP, $1 \mu$ M WAY $120,491,10 \mu \mathrm{M}$ WAY 120,491 , $10 \mu \mathrm{M}$ glyburide. Activity was recorded for $1 \mathrm{~min}$ after each addition. In one patch from each of four rats, WAY 120,491 caused a dose-dependent partial reversal of the ATP-induced inactivation of channel activity (fig. 1). Glyburicie ( 10 , $\mathrm{M}$ ) almost completely reversed the activation of channel activity caused by WAY 120,491 (fig. 1). WAY 120,491 had no effect on $\mathrm{Ca}^{2+}$. activated $\mathrm{K}^{+}$channels inactivated by the absence of $\mathrm{Ca}^{2+}$ (data not shown).

\subsection{Whole cell configuration}

Stable baseline current-voltage relationships were obtained after an initial 3 min equilibration period (the decrease in $\mathrm{K}^{+}$current observed during this period was probably duc to the reduction in free $\mathrm{Ca}^{2+}$ caused by equilibration of the cytoplasm with the $\mathrm{Ca}^{2+}$. buffered pipette solution). Figure 2 (top) presents the results of a representative experiment in which outward $\mathrm{K}^{+}$current was measured under control conditions and after the addition of $10 \mu \mathrm{M}$ WAY 120,491 and $10 \mu \mathrm{M}$ glyburide. The mean response to these compounds is presented in the current vs voltage plot in the bottom part of fig. 2 .

\section{Discussion}

The results of this study support and extend previous work on the mechanism of the vasodilatory and antihypertensive action of WAY 120,491. It is now apparent that the WAY 126,491-induced increase in $\mathrm{K}^{+}$efflux observed in previous studies occurs via an increase in the open probability of ATP-sensitive K channels. This mechanism of action is the same as that of cromakalim, a structural relative. Standen et al. (1989) reported a direct activating effect of cromakalim on a $K_{\Lambda T P}$ in mesenteric artery from the rabbit that was inhibited by glyburide.

In the whole cell configuration, the increase in outward $\mathrm{K}^{+}$current induced by $10 \mu \mathrm{M}$ WAY 120,491 was eliminated by the specific antagonist of $K_{A T p}$, glyburide. This result parallels work done at the tissue level in which WAY 120,491 increased ${ }^{42} \mathrm{~K}$ and ${ }^{46} \mathrm{Rb}$ efflux from rabbit aorta and rat portal vein, and glyburide inhibited the increase (Edwards et al., 1490, Lodge et al., 1991).

The single channel data provide direct confirmation that WAY 120,49] activates a $\mathrm{K}_{\text {ATP }}$ in vascular smooth muscle. In this respect, it is similar to its structural relative, cromakalim.

\section{References}

Chang D., P.S. Hsich and D.C. Dawson. IO88, CALCIUM: A program in BASIC for calculating the composition of solutions with specified free concentrations of calcium. magnesiom and other divalent cations, Computers Biol. Med. 18, 351.

Edwards, G.. A.11. Weston and G. Oshiro, 19u(1, Some eflects of WAY-124,491 on electrical and mechanical activity and on $" \mathrm{~K} /{ }^{\text {to }} \mathrm{Rl}$, efllux in rat blood vessels. FASEB J. 4. A746.

Falotico. R., J. Keiser, B. Hatrtlein. W-M. Cheung and A. Tobia, 1989, Increased vasodilator responsiveness to BRL 34915 in spontaneously hypertensive versus normotensive rats, P.S.E.B.M. 190. 179)

Furspan, P.B. and R.C. Wehb. Decreased ATP sensitivity of a $\mathrm{K}^{+}$ channel and enhanced valscular smooth muscle relaxation in genetically hypertensive rats. Am. J. Physiol. (in press).

Lodge. N., R.B. Cohell. (.N, Havens and T.J. (olitsky, 1991. The effects of the putative polassium channel aclivator WAY-|2(7.49| on ${ }^{\mathrm{N}} \mathrm{R}$ b efflux from the rabbit aorla, J. Pharmacol. Exp. Ther. $256,6.39$.

Oshiro, (i.T. and T.J. Colatsky, 1991, Colikalim (WAY-120.491); ; benzopyran with long duration of action, in: Currenl Drugs: Potassium Channel Modulators, Conmercial and Therapeutic Overview, ed. I.J. Tarr (Current Patents, Lid., Lomdon? p. KCMB20.

Richards, N.W., R.J. Lowy, S.A. Ernst and D.C, Diwson 1989. Two $K^{\prime}$ channel typess muscarinic agonist-activaled and inwardly rectifying, in a (I secretary epithelium: the avian sall gland, J. Gen. Physiol. 93, 1171

Standen. N.B.. J.M. Quayle. N.W. Davies, J.F. Brayden. Y. Iluang and M.T. Nelson, 1989, Hyperpolarizing valsodilators activate ATP-sensitive $K^{*}$ channels in arterial smooth muscle. Science 245, 177. 